\title{
Exposure as Collected Reason for Dose Adjustment
}

National Cancer Institute

\section{Source}

National Cancer Institute. Exposure as Collected Reason for Dose Adjustment. NCI

Thesaurus. Code C117495.

The explanation given as to why the collected exposure was adjusted. 